\title{
Sickle cell avascular necrosis: Prevalence and clinical profiles in a tertiary hospital northwestern Nigeria
}

\author{
Sani Awwalu, Abdulaziz Hassan, Ibrahim U. Kusfa, Aliyu D. Waziri, Ismaila N. Ibrahim, \\ Garba Yahaya \\ Department of Haematology and Blood Transfusion, Ahmadu Bello University Teaching Hospital, Zaria, Nigeria
}

\begin{abstract}
Acute painful crises are the hallmark of Sickle Cell Anaemia (SCA). However, chronic daily pain also occurs in SCA patients with a high frequency. Avascular Necrosis (AVN) of the femur is an important cause of chronic pain and adversely affects their quality of life. The aim is to determine the prevalence of AVN among SCA patients in Zaria and describe some of its clinical and laboratory features. A cross-sectional study of 58 SCA patients in steady state. Data on gender, age, presence of radiologically diagnosed AVN, number of pain crises, blood transfusions in the previous 12 months and laboratory parameters were collated. Data were analyzed using JASP version 0.11.1.0. A critical level of $\alpha$ of 0.05 was set. Females constituted 40 out of $58(69.0 \%)$ of the study participants. The median age was $23(19.8,28.0)$ years. AVN was present in 6 out of $58(10.3 \%)$. There was no relationship between gender and AVN (FET, p=1.00, OR=0.889 95\% CI 0.147, 5.359). There was no age difference between patients with AVN and those with-
\end{abstract}

Correspondence: Sani Awwalu, Haematology Department, Ahmadu Bello University Teaching Hospital, Zaria, Nigeria.

Tel.: +2348069429285

E-mail: sawniteriders@gmail.com

Key words: Avascular necrosis; sickle cell anaemia.

Contributions: SA: Concepts; SA, AH, IUK: Definition of intellectual content; SA, ADW, INI, GY: Literature search; SA, ADW: Data acquisition; SA, AH: Data analysis; SA, AH, IUK, ADW, INI: Statistical analysis; SA, AH, IUK, ADW: Manuscript editing; SA, AH, IUK, ADW, INI, GY: Design, Manuscript preparation, Manuscript review, Final approval.

Conflict of interest: The authors declare no potential conflict of interest.

Ethics approval and consent to participate: Institutional ethical approval was obtained from the Ahmadu Bello University Teaching Hospital Health and Research Ethics Committee.

Consent for publication: All participants gave informed written consent.

Availability of data and materials: Data is available upon request.

Received for publication: 9 June 2020.

Accepted for publication: 9 July 2020.

This work is licensed under a Creative Commons Attribution NonCommercial 4.0 License (CC BY-NC 4.0).

(C) Copyright: the Author(s),2020

Licensee PAGEPress, Italy

Annals of African Medical Research 2020; 3:114

doi:10.4081/aamr.2020.114 out AVN (29.92 vs 29.45, MWU=153.500, p=0.956). Patients with AVN had lower mean rank HCT levels (24.08 vs 30.13, $\mathrm{MWU}=123.500, \mathrm{p}=0.414)$, higher pain episodes $(31.67$ vs 29.25 , $\mathrm{MWU}=169.000, \mathrm{p}=0.747)$, number of blood transfusions (33.42 vs 29.05, MWU $=179.500, \mathrm{P}=0.549)$ and platelets ( 34.00 vs 28.98 , MWU $=183.000, p=0.499$ ) compared to those without AVN. Avascular necrosis is common among SCA patients in Zaria. These patients have more blood transfusions and bone pain episodes compared to those without AVN.

\section{Introduction}

Sickle Cell Anaemia (SCA), a qualitative haemoglobinopathy, is the most common monogenic disorder worldwide. It is characterized by two different types of pain: acute and chronic pain. Acute exacerbations known as vaso-occlusive crises are the most common presentations. However, syndromes of chronic pain have been shown to be important as well. ${ }^{1}$ One of the most common causes is a skeletal complication of SCA, Avascular necrosis $(\mathrm{AVN})$ or osteonecrosis.

AVN occurs due to complex interactions including compromised blood flow to the bone, cell death and attempts at regeneration. ${ }^{2}$ Although this may affect any bone, it commonly affects the femoral heads. This leads to chronic pain and limitation in mobility. It has been demonstrated to adversely affect quality of life..$^{3,4}$ This is further aggravated by limitations in effective treatment options which remain largely unsatisfactory. ${ }^{5}$

Given the protean nature of SCA and its complications it is important for locally-relevant data which will guide understanding of disease conditions to be generated. The burden of AVN among SCA patients and related clinical and laboratory changes are unknown in our environment. Hence this study sought to determine the prevalence of AVN among SCA patients and describe some of its clinical and laboratory features.

\section{Materials and Methods}

This was a cross sectional study in which SCA patients in steady state were consecutively enrolled from the Ahmadu Bello University Teaching Hospital (ABUTH) Haematology Clinic, following acquisition of institutional ethical approval. It was estimated that, assuming a $15.9 \%$ prevalence of AVN, ${ }^{6}$ a minimum sample size of 52 is required to have a $95 \%$ confidence of predicting the population prevalence with an absolute precision of $10 \%$. However, a sample size of 58 will be required to compensate for a $10 \%$ non-response rate. Data on gender, age, presence of radiologically diagnosed AVN (X-ray), number of pain crises and blood transfusions in the previous 12 months were collated. Full blood count was conducted and data on haematocrit (HCT), white blood cell (WBC) and platelet counts were collated. 
Data were analyzed using Microsoft Excel 2016 and JASP 0.11.1.0. ${ }^{7}$ Qualitative variables were summarized using percentages. The distribution of quantitative variables was assessed using skewness and kurtosis and means \pm Standard Deviation (SD) and medians [IQR $\left(25^{\text {th }}, 75^{\text {th }}\right.$ percentiles $\left.)\right]$ were used to summarize normally and non-normally distributed variables respectively. Mann Whitney U tests were used to assess the distribution of continuous variables across categories of qualitative variables. A critical level of $\alpha$ of 0.05 was set.

\section{Results}

Females constituted 40 out of $58(69.0 \%)$ of the study participants. The median age was $23(19.8,28.0)$ years (Table 1). A summary of quantitative variables is presented in Figure 1. AVN was present in 6 out of $58(10.3 \%)$. There was no relationship between gender and AVN (FET, $\mathrm{p}=1.00, \mathrm{OR}=0.88995 \%$ CI $0.147,5.359)$. There was no age difference between patients with AVN and those without AVN (29.92 vs 29.45, MWU=153.500, $\mathrm{p}=0.956$ ). Patients with AVN had lower mean rank HCT levels compared to those without AVN (24.08 vs 30.13, $\mathrm{MWU}=123.500, \mathrm{p}=0.420$; Table 3 ).

\section{Discussion}

The prevalence of AVN in this study is comparable to that reported by Akpan and Uboh (2018) among SCA patients in Uyo, Nigeria. ${ }^{8}$ However, our findings are lower than reports from IleIfe, Nigeria (15.9\%) and Saudi Arabia (21.7\%) but higher than the reports from Enugu Nigeria. ${ }^{6,9,10}$ These variations may be due to differences in study designs; the previous studies were retrospective reviews, ours was a cross sectional study. Unstudied differ- ences in genetic make-up and environmental factors may also be responsible for these variations. This is because the number of alpha thalassemia genes have been demonstrated to have a strong relation with increasing prevalence of AVN..${ }^{11}$ Our findings suggest comparable median ages between those with and those without AVN. However, this does not imply absence of any temporal difference in occurrence because of our study design. It is worthy of note that the age box plots indicate that the participants with AVN have a higher distribution of older age compared to those without AVN. The peak incidence of AVN has been reported to be in the 21-30 year age group. ${ }^{6}$ It is possible there is a delay in diagnosis due to the mode of diagnosis of AVN especially in resource constrained settings which relies predominantly on X-rays instead of Magnetic Resonance Imaging (MRI) which exhibits better discriminatory ability in early detection and staging of AVN. ${ }^{12,13}$ Hence, patients may be treated repeatedly for a long-time hip pain before a definitive diagnosis becomes obvious by the X-ray. ${ }^{14}$

We have interpreted our findings in context of the interval estimates and effect sizes rather than relying solely on statistical significance. This approach is the subject of recent calls by different

Table 1. Summary of variables.

\begin{tabular}{lc} 
Variable & Mean (Median) \\
Age (years) & $23.00(19.8,28.0)$ \\
Number of pain episodes in previous 12 months & $2.0(1.0,6.0)$ \\
\hline Number of blood transfusions in previous 12 months & $0.0(0.0,0.3)$ \\
Haematocrit $(\%)$ & $23.0 \pm 3.6$ \\
\hline White Blood Cell $\left(\mathrm{x} 10^{9} / \mu \mathrm{L}\right)$ & $0.6 \pm 3.0$ \\
Platelets $\left(\mathrm{x} 10^{9} / \mu \mathrm{L}\right)$ & $456.7 \pm 146.1$ \\
\hline
\end{tabular}

Table 2. Distribution of variables across avascular necrosis categories.

\begin{tabular}{|c|c|c|c|c|}
\hline Variable & AVN & Mean Rank & MWU & p \\
\hline Haematocrit (\%) & $\begin{array}{l}\text { Absent } \\
\text { Present }\end{array}$ & $\begin{array}{l}30.13 \\
24.08\end{array}$ & 123.500 & 0.414 \\
\hline White Blood Cell counts (x $\left.10^{9} / \mu \mathrm{L}\right)$ & $\begin{array}{l}\text { Absent } \\
\text { Present }\end{array}$ & $\begin{array}{l}29.35 \\
30.83\end{array}$ & 164.000 & 0.848 \\
\hline Platelets $\left(\times 10^{9} / \mu \mathrm{L}\right)$ & $\begin{array}{l}\text { Absent } \\
\text { Present }\end{array}$ & $\begin{array}{l}28.98 \\
34.00\end{array}$ & 183.000 & 0.499 \\
\hline Age (years) & $\begin{array}{l}\text { Absent } \\
\text { Present }\end{array}$ & $\begin{array}{l}29.45 \\
29.92\end{array}$ & 158.500 & 0.959 \\
\hline Bone pains in the previous 12 months & $\begin{array}{l}\text { Absent } \\
\text { Present }\end{array}$ & $\begin{array}{l}29.25 \\
31.67\end{array}$ & 169.000 & 0.747 \\
\hline Blood transfusions in the previous 12 months & $\begin{array}{l}\text { Absent } \\
\text { Present }\end{array}$ & $\begin{array}{l}29.05 \\
33.42\end{array}$ & 179.500 & 0.433 \\
\hline
\end{tabular}

Table 3. Effect Sizes for Relationships of Variables Between Categories of Avascular Necrosis.

\begin{tabular}{|c|c|c|c|}
\hline \multirow[t]{2}{*}{ Variables } & \multirow[t]{2}{*}{ Rank Bi-serial Correlation } & \multicolumn{2}{|c|}{$95 \%$ Confidence Interval } \\
\hline & & Lower & Upper \\
\hline Age (years) & 0.016 & -0.443 & 0.468 \\
\hline Pain in last 12 months & 0.083 & -0.387 & 0.519 \\
\hline Blood transfusion in last 12 months & 0.151 & -0.328 & 0.568 \\
\hline Hematocrit (\%) & -0.208 & -0.607 & 0.274 \\
\hline White Blood Cell count (x109\%/L) & 0.051 & -0.414 & 0.496 \\
\hline Platelets $\left(\times 10^{9} / \mathrm{L}\right)$ & 0.173 & -0.307 & 0.583 \\
\hline
\end{tabular}




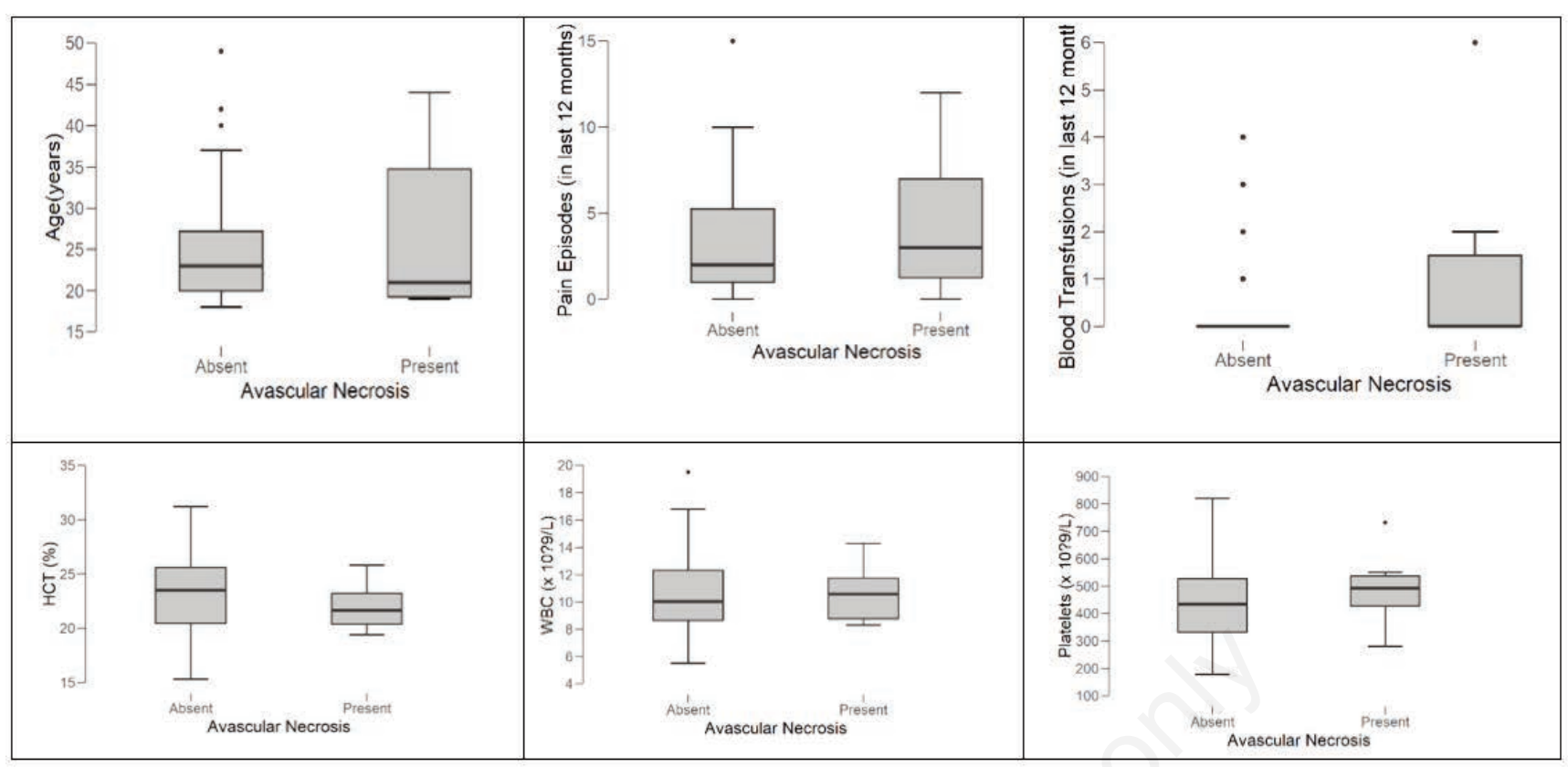

Figure 1. Box plots indicating medians, $25^{\text {th }}$ and $75^{\text {th }}$ percentiles and extreme values of continuous variables between participants with and without avascular necrosis.

groups of statisticians. ${ }^{15,16}$ The interval estimates for effect sizes in this study indicate the differences may range from medium to large in the general population. These reflect the low power of the secondary analyses in this study. It is important to note that only multicentre studies will be able to give a large number of patients with AVN for adequate comparisons. Hence, we advocate for larger future multicenter studies so that larger sample sizes may unravel more precise relationships.

The absence of any relationship between gender and AVN in this study is contrary to what is expected. There is greater Nitric Oxide bioavailability and response among female SCD patients compared to males. ${ }^{17}$ The links between endothelial Nitric Oxide Synthase (eNOS) and AVN with different polymorphisms in the eNOS gene have been extensively studied. ${ }^{18-20}$ While the point estimate for risk suggests that female gender appears to be protective for AVN, our data also suggests the possibility of increased occurrence of AVN among females. What we do not know is whether our female SCA patient have comparable expression of $\mathrm{NO}$ as demonstrated in this study or whether other as yet unstudied factors may be responsible for our finding.

The relatively lower haematocrit levels and higher rates of bone pain crises among patients with AVN in this study is similar to the findings of Madu et al. among SCA patients in Enugu Nigeria. This phenomenon is also projected among a subset of the landmark Cooperative Study of Sickle Cell Disease cohort who had concomitant alpha thalassaemia. ${ }^{11}$ This then raises the question of the need to determine the pattern of concomitant alpha thalassaemia and any effect this may have among our patients.

This study also reveals higher frequency of blood transfusion among patients with AVN. Repeated, severe haemolysis while necessitating blood transfusion lead to decreased bioavailability of NO due to the mopping up effects of cell-free haemoglobin and perturbations as a result of the action of arginase on arginine. The ensuing vasculopathy may contribute the evolution of AVN. ${ }^{21}$

\section{Conclusions}

AVN is common among SCA patients in Zaria. These patients have more blood transfusions and bone pain episodes as well as lower haematocrit levels and higher platelet counts compared to those without AVN.

\section{References}

1. Brandow AM, Zappia KJ, Stucky CL. Sickle cell disease: a natural model of acute and chronic pain. Pain 2017;158:S7984.

2. Shah KN, Racine J, Jones LC, Aaron RK. Pathophysiology and risk factors for osteonecrosis. Curr Rev Musculoskelet Med 2015;8:201-9.

3. Matos MA, Silva LLDS, Alves GB, et al. Necrosis of the femoral head and health-related quality of life of children and adolescents. Acta Ortop Bras 2018;26:227-30.

4. Mosaku SK, Oyekunle AA, Aneke JC, et al Avascular necrosis significantly impairs quality of life in sickle cell disease. J Clin Sci 2015;12:41-7.

5. Martí-Carvajal AJ, Solà I, Agreda-Pérez LH. Treatment for avascular necrosis of bone in people with sickle cell disease. Cochrane Datab Syst Rev 2016;8:CD004344.

6. Akinyoola AL, Adediran IA, Asaleye CM. Avascular necrosis of the femoral head in sickle cell disease in Nigeria: a retrospective study. Niger Postgrad Med J 2007;14:217-20.

7. JASP Team (2019). JASP (Version 0.11.1).

8. Akpan IS, Uboh EE. The pattern of morbidity in adult Nigerians with sickle cell anaemia: A tertiary healthcare setting perspective. Int J Health Sci Res 2018;8:18-27.

9. Alhumaid AM, Aleidi AS, Alfakhri AS, et al Clinical features 
and outcome of sickle cell anemia in a tertiary center: A retrospective cohort study. J Appl Hematol 2018;9:22-8

10. Madu AJ, Madu AK, Umar GK, et al. Avascular necrosis in sickle cell (homozygous S) patients: Predictive clinical and laboratory indices. Niger J Clin Pract 2014;17:86-9.

11. Milner PF, Kraus AP, Sebes JI, et al. Sickle cell disease as a cause of osteonecrosis of the femoral head. N Engl J Med 1991;325:1476-81.

12. Zhang YZ, Cao XY, Li XC, et al. Accuracy of MRI diagnosis of early osteonecrosis of the femoral head: a meta-analysis and systematic review. J Orthop Surg Res 2018;13:167.

13. Azzali E, Milanese G, Martella I, et al. Imaging of osteonecrosis of the femoral head. Acta Biomed 2016;87:6-12.

14. Hsu H, Nallamothu SV. Hip Osteonecrosis. StatPearls 2019. Available

from: https://www.ncbi.nlm.nih.gov/books/NBK499954/. [Updated 2019 Jun 17].

15. Wasserstein RL, Schirm AL, Lazar NA. Moving to a World Beyond " $p<0.05$ ”. Am Stat 2019;73:1-19.
16. Amrhein V, Greenland S, McShane B. Scientists rise up against statistical significance. Nature 2019;567:305-7.

17. Gladwin MT, Schechter AN, Ognibene FP, et al. Divergent Nitric Oxide Bioavailability in Men and Women with Sickle Cell Disease. Circulation 2003;107:271-8.

18. Zhao X, Yang F, Sun L, Zhang A. Association between NOS3 polymorphisms and osteonecrosis of the femoral head. Artif Cells Nanomed Biotechnol 2019;47:1423-7.

19. Zhang GP, Sun JN, Wang J, et al. Correlation between polymorphism of endothelial nitric oxide synthase and avascular necrosis of femoral head. Int $\mathrm{J}$ Clin Exp Med 2015;8:18849-54.

20. Zheng L, Wang W, Ni J, et al. The association of eNOS gene polymorphism with avascular necrosis of femoral head. PLoS One 2014;9:e87583.

21. Kato GJ, Gladwin MT, Steinberg MH. Deconstructing sickle cell disease: reappraisal of the role of hemolysis in the development of clinical subphenotypes. Blood Rev 2007;21:37-47. 